\title{
Effect of Protected Corn Oil Supplementation Ratio on Ruminal Fatty Acids Profile
}

\author{
Mohammad Sofi'ul Anam ${ }^{1}$, Lies Mira Yusiati ${ }^{1, *}$, Chusnul Hanim ${ }^{1}$, Zaenal \\ Bachruddin $^{1}$ and Andriyani Astuti ${ }^{1}$ \\ ${ }^{1}$ Faculty of Animal Science, Universitas Gadjah Mada, Yogyakarta \\ ${ }^{*}$ Corresponding author. Email: liesmira@ugm.ac.id
}

\begin{abstract}
The study was designed to evaluate the effect of non- and protected corn oil supplementation in the series of ratios on the in-vitro ruminal fatty acid profile. Corn oil was protected by blending skim milk powder and corn oil (2:1) and adding formaldehyde at a concentration of 1,5\%. The substrate as basal diet consisted of Elephant grass (Pennisetum purpureum) and wheat bran, with the ratio 60\%:40\%-based on dry matter. The feed substrate was supplemented with non- and protected corn oil (PCO) following different combination ratio treatments: T0: $0 \%$ and $0 \%$ (unsupplemented group), $\mathrm{T} 1: 5 \%$ and $0 \%, \mathrm{~T} 2: 3.75 \%$ and $1.25 \%, \mathrm{~T} 3: 2.5 \%$ and $2.5 \%$, T4: $1.25 \%$ and $3.75 \%$, T5: $0 \%$ and $5 \%$. The effects of these substances on the ruminal fatty acid profile were investigated using in vitro ruminal fermentation method (Tilley and Terry, 1963). The findings showed that $\mathrm{T} 1, \mathrm{~T} 2$, and $\mathrm{T} 3$ significantly $(\mathrm{P}<0.01)$ increased stearic acid $(18: 0)$ and vaccenic acid (trans-11, C18:1). The highest total saturated fatty acid (SFA) was on T1. Besides, T3, T4, and T5 significantly increased linoleic acid (C18:2n6c), linolenic acid (18:3n-3), total monounsaturated fatty acid (MUFA), and polyunsaturated fatty acid (PUFA). No treatment effect was observed for lauric acid (C12:0), myristic acid (C14:0), pentadecanoic acid (C15:0), palmitic acid (C16:0), arachidic acid (C20:0), behenic acid (C22:0), oleic acid (C18:1), $\gamma$ linolenic acid (C18:3-6). This study demonstrated that increasing the proportion of protective forms at the same ratio of corn oil supplementation increased linoleic acid (18:2n6c), linolenic acid (18:3n-3), MUFA, PUFA and reduced the SFA profiles in the rumen.
\end{abstract}

Keywords: Corn oil, fatty acids, protected, corn oil, PUFA, supplementation,

\section{INTRODUCTION}

Animal meat from ruminants contains abundant saturated fatty acids as a result of the rumen microbe's biohydrogenation process, which transforms unsaturated fatty acids (UFA) from the food to saturated fatty acids (SFA) [1]. Red meat contains a significant amount of SFA, which some customers dislike. Consumption of saturated fats, particularly lauric acid, myristic acid, palmitic acid, and stearic acid, is related to a higher risk of coronary heart disease [2]. The presence of a biohydrogenation process in the rumen can cause UFA, such as linoleic fatty acid and linolenic acid, in feed to be found in meat at low concentrations [3], which is only about $10 \%$ remaining and combining in tissue lipids [4] while $90 \%$ of the UFA will be hydrogenated into SFA [5].
Additionally, a high-fat level in the feed might be used to provide cattle with alternate energy. However, feeding ruminants an excessive amount of fat $>5 \%$ of the total diet) might deplete microbial populations and disturb microbial activity necessary for fiber digestion [6]. According to Vafa et al. [7], the application of canola oil, fish oil, or both mixture dramatically reduced the dry matter and organic matter digestibility of the diet, which was linearly related to increasing oil levels (2\%-6\%).

As a result, one strategy to increase the UFA content of ruminant meat was to include sources of UFA from oil with a high polyunsaturated fatty acid (PUFA) concentration, one of which is corn oil. According to Dwiputra et al. [8], the fatty acid composition of corn oil is $19-49 \%$ oleic acids, $34-62 \%$ linoleic acids, $8-12 \%$ palmitic acids, $2.5-4.5 \%$ stearic acids, $0.1 \%$ myristic acids, $0.1 \%$ palmitoleic acids, and $1.2 \%$ linolenic acids. St-Onge and Travers [9] stated that corn oil contains 
$57.7 \%$ of PUFA, $27.6 \%$ MUFA and some UFA of $13 \%$ of total fatty acids. By supplementing the ruminant diet with corn oil, it is hoped that the PUFA content in meat products will also increase. However, a method is needed to reduce the biohydrogenation mechanism in the rumen, one of which is using fat protection. This might be accomplished using aldehyde, which forms a strong bond with the amino acid in protein [10]. However, not many studies have examined the level of fat protection required in the same level of oil supplementation in a feed ration. As a result, this study investigated the effect of supplemented non-and protected corn oil in various ratios on the in-vitro ruminal fatty acid profile.

\section{MATERIALS AND METHODS}

\subsection{Preparation and Treatment}

The approach for encapsulating polyunsaturated fatty acids (PUFA) followed Tiven et al. [11]. Corn oil, as a source of PUFA, was blended evenly with skim milk powder in a 1:2 ratio. Formaldehyde $37 \%$ pro analysis, as a source of aldehyde, was diluted into the mixture at a concentration of $1.5 \%$ and evenly mixed to generate a protected corn oil. After that, non- and protected corn oil were supplemented to the feed substrate concerning dry matter content (DM basis). Six different combination proportions were shown in Table 1, which the total ratio supplementation on each treatment was 5\% DM of basal diet.

Table 1. The combination ratio of non- and protected corn oil on each treatment

\begin{tabular}{|l|l|l|l|}
\hline \multirow{2}{*}{ Treatment } & \multicolumn{2}{|l|}{ Combination Ratio $(\%)^{1}$} & \multirow{2}{*}{ Total (\%) } \\
\cline { 2 - 3 } & CO & PCO & \\
\hline T0 & 0.00 & 0.00 & 0.00 \\
\hline T1 & 5.00 & 0.00 & 5.00 \\
\hline T2 & 3.75 & 1.25 & 5.00 \\
\hline T3 & 2.50 & 2.50 & 5.00 \\
\hline T4 & 1.25 & 3.75 & 5.00 \\
\hline T5 & 0.00 & 5.00 & 5.00 \\
\hline
\end{tabular}

${ }^{1} \mathrm{CO}=$ corn oil without protection, $\mathrm{PCO}=$ protected corn oil

\subsection{In-vitro Fermentation}

As the source of rumen microbes, we used rumen liquor from cannulated Bali cattle which was subjected to a one-week dietary assessment (adaptation period). Rumen fluid was collected in the morning before feeding, then it was filtered through gauze and placed in a flask adjusted to $39^{\circ} \mathrm{C}$. The rumen fermentation method was adapted from the in-vitro approach [12] modified by Utomo et al. [13]. Rumen liquor buffer was mixed in a $1: 4(\mathrm{v} / \mathrm{v})$ ratio. Fifty milliliters buffered rumen solution was poured into a $100 \mathrm{~mL}$ glass tube containing $500 \mathrm{mg}$ feed substrate. For each treatment, a triplicate fermentor was incubated at $39^{\circ} \mathrm{C}$ for $48 \mathrm{~h}$. At the end of fermentation, the feed substrate was filtered using a silica disk, and the rumen fluid was collected in a $15 \mathrm{~mL}-$ conical tube. The collected rumen fluid was used for fatty acid profile analysis.

\subsection{Fatty acids analysis}

Samples in the form of rumen fluid were prepared using the AOAC [14] procedure, which consisted of two stages: hydrolysis of the sample and methylation. The sample from the extraction was methylated using $1.5 \mathrm{~mL}$ of methanolic sodium, incubated for 10 minutes, then added $2 \mathrm{~mL}$ of boron trifluoride methanol complex, incubated for 10 minutes, and then extracted with $1 \mathrm{~mL}$ of N-Heptane and $1 \mathrm{~mL}$ of saturated $\mathrm{NaCl}$. The upper supernatant as fatty acids methyl ester (FAME) was put into the vial to be injected into the Gas Chromatography (GC). The FAME analysis was carried out with GC following the procedure by Jenkins [15], where the GC was equipped with an autoinjector, autosampler, and flame ionization detector (FID) (Shimadzu 2010. Kyoto, Japan). The carrier gas was helium, and the temperature was adjusted at $35^{\circ} \mathrm{C}$ for 2 minutes, increasing at $190^{\circ} \mathrm{C}$ every $12^{\circ} \mathrm{C} /$ minute for 39 minutes. The temperature was then raised to $218^{\circ} \mathrm{C}$ at a rate of $20^{\circ} \mathrm{C} / \mathrm{min}$ for the next 20 minutes. The injector and detector temperatures were set at $250^{\circ} \mathrm{C}$. The total retention time was 60 minutes.

\subsection{Statistical analysis}

All data were subjected to analysis of variance (ANOVA) using SPSS version 20. Mean differences between treatment groups were analyzed using Duncan's multiple range test, considering at $p$-value $<0.01$.

\section{RESULTS AND DISCUSSION}

Ruminal fatty acids profile affected by protected corn oil supplementation in various ratios was shown in Table 2 . The results showed that combination treatments in $\mathrm{T} 1$, $\mathrm{T} 2$, and $\mathrm{T} 3$ generated less stearic acid as compared to the control treatment $(\mathrm{P}<0.01)$. Increasing protected corn oil supplementation, the $\mathrm{T} 4$ and $\mathrm{T} 5$ treatment showed the lower stearic acid (C12:0) than the $\mathrm{T} 1, \mathrm{~T} 2$, and $\mathrm{T} 3$ treatment $(\mathrm{P}<0.01)$. It indicated that the higher proportion of protected corn oil supplementation would produce the lower stearic acid (C12:0) in the rumen. It also showed that increasing oil protection levels would reduce the rumen's biohydrogenation process, producing stearic fatty acids (C12:0) to be lower [16, 17]. Byers and Schelling [18] stated that fatty acid esters entering the rumen would be hydrolyzed rapidly and extensively by Anaerovibrio lipolytica bacteria into free fatty acids and glycerol. The unsaturated free fatty acids will undergo isomerization and biohydrogenation by Butirivirio fibrisolvens and other microbes. So, the 
Table 2. Fatty acids profile at $48 \mathrm{~h}$ of incubation

\begin{tabular}{|c|c|c|c|c|c|c|c|c|}
\hline \multirow{2}{*}{ Items $^{1}$} & \multicolumn{6}{|c|}{ Treatments $^{2}$} & \multirow{2}{*}{- SEM $^{3}$} & \multirow{2}{*}{$p$-value } \\
\hline & TO & $\mathrm{T} 1$ & T2 & T3 & $\mathrm{T} 4$ & T5 & & \\
\hline Lauric, C12:0ns & 3.14 & 3.85 & 3.43 & 3.35 & 3.11 & 3.10 & 0.171 & 0.843 \\
\hline Myristic, C14:0ns & 3.36 & 3.12 & 3.02 & 2.76 & 2.39 & 3.23 & 0.154 & 0.549 \\
\hline Pentadecanoic, C15:0ns & 1.01 & 1.06 & 1.06 & 1.16 & 0.93 & 0.99 & 0.056 & 0.926 \\
\hline Palmitic, $16: 0^{\text {ns }}$ & 28.22 & 24.89 & 24.64 & 24.94 & 24.46 & 23.31 & 0.786 & 0.663 \\
\hline Stearic, C18:0 & $51.72^{\mathrm{a}}$ & $45.97^{\mathrm{b}}$ & $45.78^{b}$ & $43.67^{\mathrm{bc}}$ & $43.45^{c}$ & $42.87^{c}$ & 0.811 & 0.001 \\
\hline Arachidic, C20:0ns & 1.20 & 1.15 & 1.16 & 1.21 & 1.17 & 1.15 & 0.336 & 0.994 \\
\hline Behenic, C22:0ns & 0.13 & 0.22 & 0.20 & 0.25 & 0.25 & 0.13 & 0.018 & 0.281 \\
\hline Oleic, C18:1n9c ns & 6.13 & 9.47 & 9.5 & 10.76 & 12.75 & 14.02 & 1.168 & 0.500 \\
\hline $\begin{array}{l}\text { Vaccenic acid, trans-11, } \\
\text { C18:1 }\end{array}$ & $2.59^{a}$ & $6.52^{\mathrm{bcd}}$ & $6.77^{\mathrm{cd}}$ & $6.97^{d}$ & $5.93^{b c}$ & $5.83^{b}$ & 0.371 & 0.002 \\
\hline Linoleic, C18:2n6c & $2.08^{a}$ & $3.42^{b}$ & $3.97^{b c}$ & $4.15^{\mathrm{bcd}}$ & $4.69^{\mathrm{cd}}$ & $4.98^{d}$ & 0.249 & 0.002 \\
\hline Linolenic, C18:3n-3 & $0.29^{a}$ & $0.36^{\mathrm{ab}}$ & $0.39 \mathrm{bc}$ & $0.41^{\mathrm{bcd}}$ & $0.46^{c d}$ & $0.48^{d}$ & 0.018 & 0.003 \\
\hline Y-linolenic, C18:3-6ns & 0.12 & 0.15 & 0.16 & 0.25 & 0.29 & 0.29 & 0.028 & 0.392 \\
\hline SFA & $89.26^{a}$ & $82.59^{b}$ & $79.63^{b}$ & $77.02^{b}$ & $74.76^{b}$ & $74.85^{\mathrm{b}}$ & 1.337 & 0.000 \\
\hline MUFA & $8.41^{a}$ & 14.99ab & $16.27^{c}$ & $18.39^{b c d}$ & $19.69^{\mathrm{cd}}$ & $19.28^{d}$ & 1.089 & 0.004 \\
\hline PUFA & $2.49^{a}$ & $3.93^{a b}$ & $4.50^{\mathrm{bc}}$ & $4.81^{\mathrm{bcd}}$ & $6.11^{\mathrm{cd}}$ & $6.57^{d}$ & 0.391 & 0.006 \\
\hline
\end{tabular}

${ }^{1} \%$ of total fatty acids. ${ }^{2} \mathrm{~T} 0=$ control (without oil addition), $\mathrm{CO}$ (Corn Oil); PCO (Protected Corn Oil), T1 = 5\% CO and $0 \% \mathrm{PCO}, \mathrm{T} 2=3.75 \% \mathrm{CO}$ and $1.25 \% \mathrm{PCO}, \mathrm{T} 3=2.5 \% \mathrm{CO}$ and $2.5 \% \mathrm{PCO}, \mathrm{T} 4=1.25 \% \mathrm{CO}$ and $3.75 \% \mathrm{PCO}, \mathrm{T} 5$ $=0 \% \mathrm{CO}$ and $5 \%$ PCO. ${ }^{3}$ Standard error of the mean ( $p$-value).

${ }^{\text {abcd }}$ superscripts with different letters on the same column are significantly different $(P<0.01)$

ns non-significant

complete biohydrogenation of linoleic acid (C18:2n6c) would produce stearic acid (C12:0).

Based on the data in Table 2, all treatments produced higher vaccenic acid (trans-11, C18:1) than control treatment $(\mathrm{P}<0.01)$. The linoleic acid $(\mathrm{C} 18: 2 \mathrm{n} 6 \mathrm{c})$ content in the control substrate was shallow. The vaccenic acid (trans-11, C18:1) was an intermediate fatty acid produced from linoleic fatty acid in-complete biohydrogenation. Harfoot and Hazlewood [19] explained that the biohydrogenation process of linoleic acid would begin with the isomerization step of the cis12 double bond to trans-11 and produced CLA (cis-9, trans-11 C18:2). Furthermore, the cis-9 double bond was changed into trans- 11 fatty acids (vaccenic acid-trans- 11 C18:1). That step was conducted by A-bacteria groups (Butyrivibrio fibrisolven), and the last step was hydrogenation of the trans-11 double bonds into stearic acid with the role of the B-bacteria group (Clostridium proteoclasticum).

In contrast to the effects, the $\mathrm{T} 1, \mathrm{~T} 2$, and $\mathrm{T} 3$ treatments showed higher vaccenic acid (trans-11, C18:1) than T4 and T5 treatments. Higher unprotected corn oil supplementation in the feed ration produced the higher vaccenic acid (trans-11, C18:1) in the rumen. It showed that linoleic acid $(\mathrm{C} 18: 2 \mathrm{n} 6 \mathrm{c})$ that undergoes an incomplete biohydrogenation process would produce vaccenic acid (trans-11, C18:1) as an intermediate component of linoleic fatty acid (C18:2n6c), increasing. Adeyemi et al. [20] reported that adding 6\% carotene oil would be accompanied by an increase in the proportion of vaccenic acid (trans-11 C18:1). The increase of 3\% corn oil also caused the escalation of vaccenic acid (trans11, C18:1) [21]. However, with a more significant proportion of protected corn oil supplementation, the biohydrogenation process of linoleic fatty acids (C18:2n6c) would be decreased. It was indicated by the high proportion of linoleic (C18:2n6c) and linolenic fatty acids (C18:3n-3) in the rumen fluid.

In addition, all treatments produced higher proportions of linoleic $(\mathrm{C} 18: 2 \mathrm{n} 6 \mathrm{c})$ and linolenic fatty acids (C18:3n-3) compared to the control treatment. The $\mathrm{T} 3, \mathrm{~T} 4$, and $\mathrm{T} 5$ treatments produced a higher proportion of linoleic fatty acids (C18:2n6c), linolenic fatty acids (C18:3n-3), and PUFA when compared to the T1 and T2 treatments $(\mathrm{P}<0.01)$. The most significant proportion of linoleic fatty acid (C18:2n6c) and PUFA were in the T5 treatment. It might be that the presence of fat protection would produce a lowering-biohydrogenation process. The protection of fatty acids eliminated the free groups 
in long-chain UFA so that the isomerization process did not occur. This situation caused further reactions; thus, the linoleic fatty acid did not undergo much change. Riyanto [16] showed that adding $15 \%$ of protected lemuru oil increased linoleic fatty acid (C18:2n6c) in the rumen fluid by $45.45 \%$ compared to the control treatment. According to Widiyanto [22], the supplementation of protected cotton-seed oil produced higher linoleic acid (C18:2n6c) in the rumen than cottonseed oil without protection.

\section{CONCLUSION}

This study concludes that increasing the proportion of protective forms at the same ratio of corn oil supplementation increased linoleic acid (18:2n6c); linolenic acid (C18:3n-3), MUFA, PUFA and reduced the SFA profile in the rumen.

\section{AUTHORS' CONTRIBUTIONS}

MSA, LMY and CH contributed to the designing, conducting the experiment, and preparing the first draft. $\mathrm{ZB}$ and $\mathrm{AA}$ conducted the laboratory analysis and interpreted the obtained data.

\section{ACKNOWLEDGMENTS}

We would like to thank the LPDP Scholarship, Indonesia's Ministry of Finance, for funding this research.

\section{REFERENCES}

[1] M. Lourenco, E. Ramos-Morales and R.J. Wallace, The role of microbes in rumen lipolysis and biohydrogenation and their manipulation, Animal, vol. 4, pp. 1008-1023, 2010. DOI: https://doi.org/10.1017/S175173111000042X.

[2] G. Zong, Y. Li, A.J. Wanders, M. Alssema, P.L. Zock, W.C. Willett, F.B. Hu and Q. Sun, Intake of individual saturated fatty acids and risk of coronary heart disease in US men and women: two prospective longitudinal cohort studies, British Medical Journal, vol. 355, pp. 1-11, 2016. DOI: https://doi.org/10.1136/bmj.i5796.

[3] T.C. Jenkins, R.J. Wallace, P.J. Moate and E.E. Mosley, Board-invited review: Recent advances in biohydrogenation of unsaturated fatty acids within the rumen microbial ecosystem, Journal of Animal Science, vol. 86, pp. 397-412, 2008. DOI: https://doi.org/10.2527/jas.2007-0588.

[4] J.D. Wood, M. Enser, A.V. Fisher, G.R. Nute, P.R. Sheard, R.I. Richardson, S.I. Hughes and F.M. Whittington, Fat deposition, fatty acid composition and meat quality, Meat Science, vol.
78, pp. 343-358, 2008. DOI: https://doi.org/10.1016/j.meatsci.2007.07.019

[5] J.K. Drackley, Overview of fat digestion and metabolism in dairy cows, University of Illinois, Urbana, IL, USA. pp. 1-9, 2007.

[6] L.D. Bunting, J.M. Fernandez, R.J. Fornea, T.W. White, M.A. Froetschel, J.D. Stone and K. Ingawa, Seasonal effects of supplemental fat or undegradable protein on the growth and metabolism of Holstein calves, Journal of Dairy Science, vol. 79, pp.1611-1620, 1996. DOI: https://doi.org/10.3168/jds.S00220302(96)76524-4.

[7] T.S. Vafa, A.A. Naserian, A.R. Heravi, R. Valizadeh and M.D. Mesgaran, Effects of different levels of fish oil and canola oil on in vitro dry matter and organis matter digestibility, Reseacrh Journal of Biological Sciences, vol. 4, pp. 11711174, 2009.2 DOI: https://doi.org/10.3923/rjbsci.2009.1221.1226

[8] D. Dwiputra, A.N. Jagat, F.K Wulandari, A.S. Prakarsa, D.A. Puspaningrum and F. Islamiyah, Minyak jagung alternatif pengganti minyak yang sehat, Jurnal Aplikasi Teknologi Pangan, vol. 4, pp. $\quad \mathrm{v}$-vi, 2015. http://www.jatp.ift.or.id/index.php/jatp/article/vie $\mathrm{w} / 89$

[9] M.P. St-Onge and A. Travers, Fatty acids in corn oil: role in heart disease prevention in Handbook of Lipids in Human Function, AOCS Press, Elsevier Inc, Urbana, IL., pp. 130-140, 2016.

[10] J.A. Kiernan, Formaldehyde, formalin, paraformaldehyde and glutaraldehyde: what they are and what they do, Microscopy Today, vol. 8, pp. $\quad 8-12,2000.2$ DOI: https://doi.org/10.1017/S1551929500057060

[11] N.C. Tiven, L.M. Yusiati, Rusman and U. Santoso, Effect of protected crude palm oil on rumen microbial activities and methane production. Proceedings $5^{\text {th }}$ International Seminar on Tropical Animal Production, Yogyakarta, Indonesia, $\quad$ pp 89-94, 2010. https://journal.ugm.ac.id/istapproceeding/article/ view/30417

[12] J.M.A. Tilley and R.A. Terry, A two stage technique for in vitro digestion of forage crop The Journal of British Grassland Society, vol. 18, pp. 104-111, $1963 . \quad$ DOI: https://doi.org/10.1111/j.13652494.1963.tb00335.x 
[13] R. Utomo, Modifikasi metode penetapan kecernaan in vitro bahan kering atau bahan organik, Buletin Sintetis, vol. 1, pp. 1-11, 2010.

[14] AOAC, Official Methods of Analysis. $11^{\text {th }}$ ed.. Washington: Association of Official Analytical Chemists, Washington DC, 2005.

[15] T.C. Jenkins, Technical note: Common analytical errors yielding inaccurate results during analysis of fatty acids in feed and digesta samples, Journal of Dairy Science, vol. 93, pp. 1170-1174, 2010. DOI: https://doi.org/10.3168/jds.2009-2509.

[16] J. Riyanto, Evaluasi Menir Kedelai Dan Minyak Ikan Lemuru Diproteksi Formaldehid Sebagai Sumber Asam Lemak Tidak Jenuh Untuk Komponen Ransum Induk Sapi Potong Secara In Vitro, Dissertation, Faculty of Animal Science, Universitas Gadjah Mada, Yogyakarta, 2015.

[17] A.A. Behan, T.C. Loh, S. Fakurazi, U. Kaka, A. Kaka and A.A. Samsudin, Effects of supplementation of rumen protected fats on rumen ecology and digestibility of nutrients in sheep, Animals, vol. 9, pp. 1-18, 2019. DOI: https://doi.org/10.3390/ani9070400.

[18] F.M. Byers and G.T. Schelling, Lipid in ruminant: In The Ruminant Animal Digestive Physiology and Nutrition, Prentice Hall, Englewood Cliffs, New Jersey, pp. 298-324, 1998.

[19] C.G. Harfoot, R.C. Noble and J.H. Moore, Food particles as a site for biohydrogenation of unsaturated fatty acids in the rumen, The Biochemical Journal, vol. 132, pp. 829-832, 1973. DOI: https://doi.org/10.1042/bj1320829.

[20] K.D. Adeyemi, M. Ebrahimi, A.A. Samsudin, A.A. Alimon, R. Karim, A.A. Karsani and A.Q. Sazili, Influence of carotino oil on in vitro rumen fermentation, metabolism and apparent biohydrogenation of fatty acids, Animal Science Journal, vol. 86, pp. 270-278, 2015. DOI: https://doi.org/10.1111/asj.12279.

[21] A. Irawan, The Effect of Leucaena Leucocephala And Napier Grass Ratio With Corn Oil Addition on Products of Ruminal Fermentation, Methane Production, and Nutrients Degradability In Vitro, Thesis, Faculty of Animal Science, Universitas Gadjah Mada Yogyakarta, 2018.

[22] Widiyanto, Suplementasi Minyak Biji Kapok Terproteksi Sebagai Sumber Asam Lemak Tidak Jenuh Untuk Meningkatkan Produktivitas Daging Domba Lokal Jawa Ekor Kurus Jantan Rendah Kolesterol Kaya Asam Lemak Omega 6,
Dissertation, Faculty of Animal Science, Universitas Gadjah Mada Yogyakarta, 2008. 